\title{
The Aesthetic and the Mystic Experience in Indian Theory
}

\author{
By NILS SIMONSSON
}

In the Sānkhyakārikās, the chief text of the dualistic Sānkhya philosophy, ${ }^{1}$ the world and salvation therefrom are described in compressed images as various stages of aesthetic situations. Purusa, the spiritual principle, whose only characteristic apart from being is consciousness, regards the spectacle which prakrti, primary substance, natura, gives. Existence is a theatrical show where that which takes place on the scene only acquires meaning through being regarded and enjoyed by a spectator. The spectator is totally absorbed by the show to the point of identifying himself with it, and he enjoys it. Salvation takes place when the false identification ceases, when insight into the true dualism arises, when the spectator leaves the theatre and the dancinggirl leaves the scene:

${ }^{1}$ I shall here mention some books of general interest relevant to the subject treated. Only works the use of which does not require knowledge of Sanskrit are included in this list. Those works which are quoted in the following notes are marked with an asterisk*.

SĀNKHYA:

R. Garbe, Die Sāṃhhya-Philosophie. Eine Darstellung des indischen Rationalismus. 2. Aufl., Leipzig r9r7.

A. B. Keith, The Samkhya System. A History of the Samkhya Philosophy, Calcutta-London r9r8.

* SāNKHYAKĀRIKà:

Der Mondschein der Säm̧khya-Wahrheit. Vācaspatimiçra's Sāṃkhya-tattva-kaumudī in deutscher Übersetzung, nebst einer Einleitung über das Alter und die Herkunft der Sāmkhya-Philosophie von Richard Garbe, (Abh. der K. bayerischen Akad. d. Wiss.), München I 892 .

Indisk filosofi: Sāñkhya. Inledning och översättning av Nils Simonsson. Stockholm 1955. Translation into Swedish of İ́varakṛṣna's Sãn̉khyakãrikăs and Māṭhara's commentary.

Kashmir Shivaism:

J. C. Chatterji, Kashmir Shaivaism (Being a brief introduction to the history, literature and doctrines of the Advaita Shaiva Philosophy of Kashmir, specifically called the Trika System). (Kashmir Series of Texts and Studies), Srinagar I9I4. 
"Just as the dancing-girl after having given her performance in front of the audience retires from the dance, thus Prakrti retires after having shown herself to Puruṣa,"

In the monistic Kashmir Shivaism images from the theatre are often borrowed so that the teaching may be visualized. The first two sentences (sütra) in the so-called "philosophy of recognition (pratyabhijña)" have the following literal translation:

"Consciousness, which is not dependent on anything, is the cause of the world's coming into existence. Of its own will it manifests the world on its own screen.",

The screen (literally the wall: bhitti) is the screen of a shadow-play. In order to approach the thought and prevent a dualistic interpretation, we ought perhaps to say: consciousness manifests the world on itself as screen.

As the third and final example of how terms from the field of aesthetics are employed in a religious-philosophical connection, I shall mention the bhaktimovements. In the Bengali vishnuite bhakti in particular we find that the

* Pratyabhijñāhrdayam. The Secret of Recognition. Sanskrit Text edited by the Staff of the Adyar Library. Trsl. into English by Kurt F. Leidecker. (Adyar Library Series I 8), Adyar Library 1938 .

L. Silburn. (Several works, in French, on Kashmir Shivaism, in the Publications de l'Institut de Civilisation Indienne, Paris. See also under Aesthetics: [Abhinavagupta].)

Aesthetics:

(The first three works are particularly suited for non-sanskritists as a general introduction.)

[Abhinavagupta.] Le Paramārthasāra. Texte sanskrit édité et traduit par Liliane Silburn. (Publications de l'Institut de Civilisation Indienne), Paris 1957. A very instructive survey of Abhinavagupta's theory is given by the editor and translator on pp. 10-18.

*R. Gnoli, The Aesthetic Experience according to Abhinavagupta. (Serie Orientale Roma XI.), Roma 1956. This is a translation of a chapter of the Abhinavabhärati, with an introduction and copious notes. One of the most useful contributions to the study of Indian aesthetics.

*S. K. De, Sanskrit Poetics as a Study of Aesthetics. With notes by Edwin Gerow. Berkeley and Los Angeles r 963 .

S. K. De, History of Sanskrit Poetics. 2nd. rev. ed., Calcutta 1960.

*K. C. Pandey, Indian Aesthetics. 2nd ed., (Chowkhamba Sanskrit Series. Studies

Vol. II. Comparative Aesthetics. Vol. I.), Varanasi 1959.

1 Särikhyakārikā 59 .

2 Pratyabhij̄ñăhrịayam, sūtras 1,2. 
concepts of the aesthetic theories are transferred to the religious experience: transferred and developed in order to fit this particular purpose. ${ }^{1}$

Thereby we have approached our subject.

The present attempt of giving, within a short space of time, an idea of the Indian theories concerning the aesthetic experience necessitates considerable simplifications; nor is it possible to consider the fact that the Indian accounts generally form part of a continuous dicussion where it can often be difficult to grasp each theory as a whole. I shall therefore confine myself to a discussion of certain fundamental concepts.

Let us also decide which aesthetic situation we are to have in mind. First and foremost it is to be that which occurred in the metaphor from Sānkhya which I gave as introduction: theatrical show/spectator. In other words, it is primarily a question of the experience which he who enjoys a woris of art has. The Indian theorists do not always distinguish clearly between this experience and that which the creator or the reproducer of a work of art may be supposed to have. The transmission (if such a transmission takes place at all) of the experience of the creator (author) through the reproducer (actor) to the spectator is also a problem which will not be treated here. We shall further confine ourselves to theatrical art; according to the Indians it is the highest form of art, and it is above all in connection with it that they have developed their theories. Theatre is a form of art that involves the eye as well as the ear. Aesthetic experience is, according to the Indian theorists, only obtained through the eye and the ear. With this in mind, it is worth noting, possibly with surprise, that the linguistic term for the aesthetic experience is borrowed from another field of perception, namely that of taste. The word is rasa, "taste". And that is the key concept in the most widely spread theory of beauty: the rasa-theory. Incidentally, it is not practical to speak of "beauty" as far as Indian theories are concerned: one easily gets the false impression that the Indian theories, as is the case with so many of the Occidental ones, are built up round "beautiful" objects, around discussions about the nature of art, etc. Indian speculation proceeds from a psychic state which, as we have seen, has been given the name rasa. This state, the nature of which will be discussed later, is produced or manifested not only by that which we would

${ }^{1}$ S. K. De, Early History of the Vaisnava Faith and Movement in Bengal, Calcutta I96r, pp. I66-224. 
call beautiful, lovely, but also for example by that which is terrifying, ugly, indeed by the very opposite of "beauty". In this connection let me suggest that this Indian way of tackling the problem permits a simple explanation of our joy at tragical subjects.

Two concepts are important in understanding the distinction between an aesthetic experience, rasa, and an ordinary emotion. These concepts are "generalisation" (sädhāranya) and "hindrance" (vighna). As I understand it, these two concepts are key concepts in the aesthetic theory which is closely connected with Kashmir Shivaism, and I think it is profitable to concentrate on these concepts if one wants to gain an understanding of the true purport of the theory instead of following the traditional accounts (with their difficult technical terminology: bhäva, anubhāva, vibhäva, etc.).

In short, the truth of the matter is, I think, as follows. In daily life an emotion is never wholly pure, it is always in some way mixed or hindered. For example, a feeling of joy is hindered by the fear that it may come to an end, a feeling of fear is hindered by the wish that it may come to an end. To save time I leave it to the audience to think of examples from other emotions. Let us concentrate on the example "fear". If we imagine fear as such, not related to time, place, person, object or any circumstances whatever that may act as hindrances, we have a "generalized" mental state, and it is this state which is called rasa. This state of generalized, deindividualized, pure, unhindered fear can only be obtained in an aesthetic situation. (The explanations are complicated and, perhaps, not entirely convincing; we shall not deal with them here.) This generalized state is experienced as joy. Why? To give an idea of the chain of reasoning, I shall give a commentated analysis of the famous definition of the aesthetic experience which Viśvanātha gives (or quotes?) in his Sähityadarpana. ${ }^{1}$ A direct translation would not convey much to the uninitiated.

First of all, it is important to be aware of the significance of the terms sattva, rajas and tamas. According to the Sānkhya philosophy, which postu-

\footnotetext{
1 See e.g. Kashinath Pandurang Parab's edition, Bombay I902, III, 2 sqq. The passage is treated by Gnoli, p. 55, and S.K. De, Sanskrit Poetics, p. 56. sattvodrekäd akhanda-svaprakāśânanda-cin-mayahl vedyântara-sparśa-śünyo brahmâsvāda-sahodarahll lokottara-camatkāra-prānah kaiscit pramātrbhihl svākäravad abhinnatvenâyam äsvādyate rasaḥl|
} 
lates two principles: puruṣa $=$ spirit = consciousness without any object on the one hand, prakrti =all that which is not consciousness on the other,- -according to this philosophy, prakrti is built up of three constituents, gunas. Combined in different proportions, these three constituents cause the world to come into being: physical objects, but also psychic conditions (regarded as "object" for the spirit, purusa, and in themselves without consciousness). If we confine ourselves to the physical world, we can say that sattva is the principle of that which is bright and light, tamas of that which is dark and heavy, and rajas is the principle of movement. On the psychical plane: sattva - serenity, knowledge, tamas - dullness, sluggishness, rajas - unrest, passion. The constituents always appear together, they can never be entirely isolated, but a powerful preponderance of the one or the other is possible in a given situation. Such a situation is the aesthetic situation. There sattva predominates, Viśvanātha says (sattvodreka). I interpret this as follows: in order that the experience of rasa may be rendered possible, those mental states which involve dullness, sluggishness and unrest must be eliminated. This imposes certain demands as to the external conditions when a play is to be enjoyed: the interesting thing is, I think, that all the spectators must have the same mental attitude, that there must be a collective atmosphere of serenity and elevated longing for the act of experiencing, an atmosphere which must not be broken by the presence of the uninterested or of those who lack the power of aesthetic experience. This is of importance for the generalization of the emotions. Community is a condition for aesthetic experience, just as it is for religious experience during ceremonies. Abhinavagupta has an interesting passage dealing with this question in Tantrāloka. After explaining why it is important to create one single consciousness at the theatre etc., he says: "This is the reason why, during the celebration of the cakra, etc., no individual must be allowed to enter who does not identify himself with the ceremonies and so does not share the state of consciousness of the celebrants; this would cause, in fact, a contraction of the consciousness." 1

We shall deal with the question of what this contraction is in a moment.

It is important to note that it is a necessary condition for the experiencing of rasa that one is among the select few who have the power of aesthetic

${ }^{1}$ Quoted after Gnoli, p. 70.

I3-694455 Hartman 
experience; not everyone has this power. Rasa is tasted by certain persons who are qualified (kais cit pramätṛhih ... äsvädyate rasah).

Viśvanātha then gives a characterization of rasa in four compressed word-compounds. I shall take them in a different order based on pedagogical considerations which Viśvanātha regarded as beneath his dignity. In the psychic state of rasa nothing else is perceived (vedyântara-sparśa-siunnya). This implies that which I spoke of before: that rasa is a strengthened emotion in which there is no hindrance.

The next characteristic: the aesthetic experience is essentially an astonishment which exceeds ordinary experience (lokottara-camatkāra-prāna). The word that I translated by astonishment, camatkarra, is another of the key terms in the theory of aesthetics. The term also belongs to the shivaist arsenal of terms for describing the mystic experience. It is interpreted in various ways by the theorists, frequently in such a way that it becomes a fairly abstract term expressing the highest experience without the colourful characterization conveyed by the translation "astonishment". But it is obvious that astonishment plays a major rôle in the aesthetic experience, and this is expressed in clear words by Nārāyana: "The essence of rasa is astonishment (camatkära), and it is experienced in each rasa (sarvatra); therefore-since astonishment is the essence - the rasa of wonder (adbhuto rasah) is to be found in every other rasa (sarvatrâpi)"'1. Viśvanātha says that camatkāra is synonymous for vismaya, astonishment, and he says that camatkāra is an "expansion of the mind" (citta-vistära). I think this is particularly important as it indirectly states that we are dealing with a process which leads to a higher consciousness. For if we turn to Shivaism we find that the opposite of expansion, namely contraction, samkoca, is an important term for characterizing the process that leads to individualization, the particularization of the one

\footnotetext{
${ }^{1}$ Sāhityadarpaṇa III, 3: [tad āha Dharmadattah svagranthe] rase säras camatkärah sarvatrâpy anubhüyatel tac camatkāra-säratve sarvatrâpy adbhuto rasaḥ/ [tasmäd] adbhutam evâha krtī Närāyaño rasam //iti//] Subodh Chandra Mukerjee in his work Le Rasa, essai sur l'esthétique indienne, Paris I 926, p. 52 gives this translation of the two lines: "L'étonnement est toujours ressenti comme l'essence d'un rasa; puisque l'étonnement est l'essence, un rasa est toujours un Sentiment du Merveilleux." Edwin Gerow in his notes to S.K.De, Sanskrit Poetics (see above, p. 190), 56,20 translates the second line as follows: "Wherever this strikingness (camatkāra) is found as an essential element, there you have adbhutarasa." Neither of these interpretations is acceptable.-The last line will be translated below.
} 
cosmic consciousness (Siva). Thus, the aesthetic experience implies so to speak a movement in the opposite direction. In this connection Abhinavagupta may fittingly be quoted; his words are to the following effect: "The consciousness, which is the essence of everything, enters into a state of contraction because of the difference of bodies. But, in public celebrations, it returns to a state of expansion-since all the components are reflected in each other"' He believes that the primal unity of the consciousness is restored when every individual consciousness in an assembly, with each other's help, by being reflected in each other, lose their individual contraction (which is caused by the hindrances: jealousy, ill-will, etc.). That is why it is important that all have the same mental attitude and that no-one who is uninterested is present, as mentioned above. A commentator (Jayaratha) explains that the fragmentation of consciousness is only an illusion. In the aesthetic experience and so on, when all the spectators are absorbed by the same to the exclusion of everything else, this fragmentation ceases for a time to exist and gives way to a manifestation of unity, of unlimited consciousness 2 .

We are now prepared to consider the third expression which according to Viśvanātha characterizes the aesthetic experience. It consists of consciousness, bliss and self-luminosity, all three of them akhanda, perfect (akhanda-svaprakāsânanda-cin-maya). This characterization can easily lead the reader to believe that the aesthetic experience is identical with the experiencing of brahman, the nature of which according to Vedannta is being, consciousness and bliss (sat, cit, ananda). In part, Viśvanātha approves of this view, but only, I repeat, in part: the aesthetic experience is a "twin brother" of the tasting of brahman (brahmâsvãda-sahodara), and similar citations may be adduced from other authors.

We have here obtained the suggestion of an answer to the question which was posed a moment ago: why is an unhindered, generalized emotion (a rasa) experienced as joy? It is, then, because the aesthetic experience leads us down to the profoundest layers of our being, and the innermost of our being is bliss. It thus becomes a task to define more closely the distinction between the mystic and the aesthetic experience. We shall deal with it in a moment.

1 samvit sarvātmikā deha-bhedād yā samkucet tu sāl melake 'nyonya-sanghațtapratibimbäd vikasvaräll Tanträloka XXVIII, v. 373, quoted after Gnoli, p. 69.

2 See Gnoli, p. 70. 
But first we shall mention yet another trait which distinguishes the aesthetic experience. Viśvanātha says that rasa is experienced as being undivided, just as one's own form (sväkäravad abhinnatvena). Precisely what the author has meant by this is unclear to me: how the syntactic connection between the two Sanscrit terms is to be understood could also be discussed at length. Gnoli translates: It is tasted as if it were our very being, in indivisibility. Perhaps what is meant is that in the same way as we have direct experience of ourselves without division into subject and object, in that same way we experience rasa-not as an object but as in some way identical with our being. Another interpretation is also conceivable; I mention it in order to get an opportunity to deal with an essential problem connected with the difference between the aesthetic and the mystic experience: perhaps it means that just as we, when we experience our own innermost being, our " $\mathrm{I}$ ", do not experience any distinctions, any divisions in it, in the same way we do not experience any division in rasa. This may then mean either that there is only one single rasa, or that there are several but that each rasa is uniform, without differences. Both interpretations may be reasonable when we consider the different views of the theorists.

So far we have not touched on the question whether rasa is one or several, and the discussion has been conducted in such a way that the question was rendered relatively unimportant. However, I would like to remind you of the statement quoted form Nārāyana to the effect that the rasa of wonder exists in every rasa. This, then, implies on the one hand that there are many rasas, on the other hand that Nārāyana does not appear to hold that each individual rasa is uniform, for it contains at least two components. The rasa of wonder could, of course, strictly speaking be uniform, i.e. contain only "astonishment". It may further be remembered that I said that rasa is a generalized emotion. From this it follows that there ought to be as many rasas as there are emotions. And so we have 8, 9, or Io rasas, sometimes even more, depending on the various classifications that are to be found. ${ }^{1}$ Starting from these premises it ought to be fairly easy to define the difference between the one

${ }^{1} \mathrm{~V}$. Raghavan, The Number of Rasas, Adyar 1940.-The standard list of rasas is the following: śrngāra "love", hāsya "mirth", karuna "compassion", "sadness", "grief", raudra "anger", vĩra "elevation", "enthusiasm", bhayãnaka "fear", bībhatsa "disgust", adbhuta "wonder", śānta "peace", vätsalya "tenderness". 
mystic experience, the experience of Siva, the highest consciousness, or brahman, and the aesthetic experience, which is of many kinds.

However, it becomes more difficult to define the difference when one asserts the view that the aesthetic experience also is one, and this is of course easy to do if one holds that this experience is really the experiencing of our innermost being, which is one. But this is also done without this thought seeming to be decisive: thus, in the Uttararāmacarita III, 47 , the famous poet Bhavabhūti speaks of one single rasa karuna, compassion, sadness. This karuna assumes various illusive forms (vivarta) and appears as if particularized depending on the various causes that produce it. Bhavabhūti makes a comparison with water which assumes various real forms (vikāra) such as whirlpools, bubbles and waves without ceasing to be water. However, it is probable that what Bhavabhüti here says is contingent on a particular literary connection and that it does not reflect a systematic theory'. It would also be difficult, I believe, to give a plausible psychological explanation as to why compassion should be the basis of all aesthetic experience. However, it can hardly be denied that it is dominating in many genres. Many of the greatest literary works of our culture (e.g. those of Dostoevsky, Tolstoy, Flaubert, Hamsun) are filled with compassion, sadness, melancholy. And in his essay The Philosophy of Composition, in which he describes his procedure when composing The Raven, Edgar Allan Poe says that having decided on Beauty as his province, he asked himself in which "tone" this beauty assumed its highest manifestation-"and all experience has shown that this tone is one of sadness. Beauty of whatever kind, in its supreme development, invariably excites the sensitive soul to tears. Melancholy is thus the most legitimate of all the poetical tones". "Tone", I think, must more or less equal rasa.

Nārāyana, whose interesting statement about astonishment as the essence of the aesthetic experience I have treated above, also held the opinion that rasa is one. For the fine observation that is ascribed to him is, in fact, only the first part of an argumentation; the second part is a conclusion which Dharmadatta, our informant, formulates as follows: "therefore the learned Nārāyaṇa says that only Wonder is rasa (tasmād adbhutam evâha kṛtī Närāyano rasam $)^{2}$. Whether one accepts this conclusion or not, one has to admit

${ }^{1}$ Discussed by Pandey, Indian Aesthetics, p. I 88 sqq.

2 See page I94, note $\mathbf{I}$. 
that giving astonishment a prominent place in the aesthetic experience bears witness of fine psychological observation.

When the rasa of peace (s'anta) was added to the row of rasas, the discussion received a major complication. I can only give a few hints, more by means of catchwords than by reasoning. Peace is something which is difficult, perhaps impossible, to represent on the stage. Accordingly, Mammatia did not admit śänta in drama-but permitted it in poetry! Further: is not peace rather the absence of experience-how can it then be a rasa? Another view: peace is the goal of all aesthetic experience: peace is therefore the highest rasa, indeed, according to some, the only rasa. As might be expected, the latter view creates particular difficulties if one wishes to trace the borderline between aesthetic and religious experience.

A most interesting but abstruse theory is set forth by Bhoja. In his great work Srnngãra-prakāśa ${ }^{1}$ this eminent dialectician comes to the conclusion that rasa is one, and that is śrig $\bar{a} r a$, love. However, it turns out that love in this case is not exactly the same as the rasa of love which most authors place at the head of the rasas. It is love of the Self, Self-Love (Raghavan p. 48I, 490 sqq.). This fundamental love is identified with abhimanna which is the power of subjectivation and objectivation which characterizes ahamkära, the I. Bhoja consequently identifies rasa and the I. All emotions (bhävas) are explained by Bhoja as forms of love (Raghavan p. 49I). Raghavan compares Bhoja's theory of self-love with the psycho-analytical theory of libido (p. 490 sqq.). For example, Raghavan quotes the following passage from a psycho-analytical author (Wittels): "What we love and worship in another is our own Ego, which we have exteriorised into another's personality".

Time does not permit a further discussion of the interesting theories of Bhoja. We should, however, pay particular attention to the fact that this author places the aesthetic experience in the ego, indeed identifies rasa with the ego. And it should now be obvious from the scattered material I have presented that it is of the greatest importance when defining similarities and differences between the aesthetic and the mystic experience to determine where in the psychic apparatus the aesthetic experience is placed by the various authors. In this sketch I have not wished to complicate the account by dealing with

\footnotetext{
${ }^{1}$ The standard work on Bhoja is V. Raghavan, Bhoja's Srrngāraprakāsa, Madras 1963 .
} 
the technicalities which a detailed discussion of the psychological, philosophical and religious background would entail; I have chosen instead to speak in general terms. As for Bhoja, it is for certain reasons probable that he was influenced by Sānkhya, at least as far as the problems I just touched on are concerned. And in that case one must ask oneself whether the aesthetic experience is not placed by Bhoja exceptionally low down in the hierarchy of human faculties and is an experience of a kind much inferior to that of those authors who speak of it as a twin brother of the tasting of brahman and so on. If, however, one regards the matter from another point of view, psychological rather than philosophical, one finds that Bhoja's view of the aesthetic experience is extremely subtle and profound, and in this respect probably surpasses the view of those authors who boldly place the aesthetic experience close to the very fountain of existence itself. One might suspect that these latter theorists are forced to occasionally deal too cursorily with the complicated processes that take place in the outer layers of man's psyche when experiencing art. I believe that Bhoja has realized those complications. 